\title{
CHAROPHYTES AS A NUTRIENT AND ENERGY RESERVOIR IN A TROPICAL COASTAL LAGOON IMPACTED BY HUMANS (RJ, BRAZIL)
}

\author{
PALMA-SILVA, C., ${ }^{1}$ ALBERTONI, E. F. ${ }^{1}$ and ESTEVES, F. A. ${ }^{2}$ \\ ${ }^{1}$ Laboratório de Ecologia e Limnologia, Departamento de Ciências Morfobiológicas, Fundação Universidade \\ Federal do Rio Grande, CEP 96201-900, Rio Grande, RS, Brazil \\ ${ }^{2}$ Laboratório de Limnologia, Departamento de Ecologia, Universidade Federal \\ do Rio de Janeiro, Instituto de Biologia \\ Correspondence to: Cléber Palma-Silva, Laboratório de Ecologia e Limnologia, Departamento \\ de Ciências Morfobiológicas, Fundação Universidade Federal do Rio Grande, \\ CEP 96201-900, Rio Grande, RS, Brazil, e-mail: dmbcps@ furg.br \\ Received October 21, 2002 - Accepted September 11, 2003 - Distributed August 31, 2004
}

\begin{abstract}
In the Imboassica Lagoon (22 $24^{\prime} \mathrm{S}$ and $42^{\circ} 42^{\prime} \mathrm{W}$ ) (Macaé, RJ, Brazil), two species of macroalgae of the genus Chara (C. angolensis and C. fibrosa) registered in large areas were identified. The lagoon is subject to several relevant anthropic impacts, of which untreated sewage is one of the most important. Results of the biomass distribution as analyzed in different areas of the lagoon showed values ranging from 172 to $510 \mathrm{gDW} \cdot \mathrm{m}^{-2}$. As for the nutrient concentration, the results presented large fluctuations, with carbon values ranging from 325 to $392 \mathrm{mg} . \mathrm{g}^{-1} \mathrm{DW}$, those of nitrogen, from 14 to $27 \mathrm{mg} . \mathrm{g}^{-1} \mathrm{DW}$, and of phosphorus from 0.45 to $0.85 \mathrm{mg} . \mathrm{g}^{-1} \mathrm{DW}$. This led to large fluctuations of the $\mathrm{C}: \mathrm{N}: \mathrm{P}$ ratio (from 387:24:1 to $872: 47: 1$ ). The minimum and maximum energetic values of the biomass were $9.54 \mathrm{e} 12.34 \mathrm{~kJ}^{\mathrm{g}} \mathrm{g}^{-1} \mathrm{DW}$. Smaller C:N:P ratios tended to occur in more eutrophic areas. The association between biomass and nutrient concentration showed that the highest quantities in the beds are found in oligotrophic areas. The Spearman correlation between nutrient concentration in the water column and biomass was $r_{s}=0.45$ $(p<0.05)$ for nitrogen and $r_{s}=0.50(p<0.01)$ for phosphorus $(n=30)$. The large total biomass associated with nutrient concentration and energy content indicates that Charophytes are an important biological compartment in the structure and metabolism of the lagoon.
\end{abstract}

Key words: aquatic macrophyte, biomass, nutrients, chemical composition, pollution.

\section{RESUMO}

\section{Carófitas como reservatório de nutrientes e energia em uma lagoa costeira tropical sujeita a impactos antrópicos (RJ, Brasil)}

$\mathrm{Na}$ Lagoa Imboassica, localizada em Macaé, RJ, Brasil (22 $24^{\prime} \mathrm{S}$ e $\left.42^{\circ} 42^{\prime} \mathrm{W}\right)$, foram identificadas duas espécies de macroalgas do gênero Chara (C. angolensis e C. fibrosa), apresentando ampla distribuição. A lagoa recebe vários impactos antrópicos, e o lançamento de esgoto não tratado é um dos mais importantes. A biomassa variou entre 172 e $510 \mathrm{gDW} \cdot \mathrm{m}^{-2} \mathrm{em}$ diferentes áreas da lagoa. A concentração de nutrientes apresentou ampla variação, com os valores de carbono entre 325 e $392 \mathrm{mg} \cdot \mathrm{g}^{-1} \mathrm{DW}$, nitrogênio entre 14 e $27 \mathrm{mg} . \mathrm{g}^{-1} \mathrm{DW}$ e fósforo entre 0,45 e $0,85 \mathrm{mg} \cdot \mathrm{g}^{-1} \mathrm{DW}$, assim as taxas C:N:P apresentaram variação de 387:24:1 a 872:47:1. Os valores mínimo e máximo de energia na biomassa foram, respectivamente, 9,54 e 12,34 kJ.g-1 DW. Há tendência de as menores taxas C:N:P ocorrerem em áreas mais eutrofizadas. Considerando os valores de biomassa e a concentração de nutrientes na biomassa, os maiores estoques de nutrientes estão associados aos bancos de Carófitas em áreas mais oligotróficas. A correlação de Spearman entre a concentração de nutrientes na coluna de água e a biomassa foi $r_{s}=0,45(p<0,05)$ para o nitrogênio e $r_{s}=0,50(p<0,01)$ para o fósforo $(n=30)$. A grande biomassa associada à concentração 
de nutrientes e os valores energéticos indicam que as carófitas são um importante compartimento biológico na estrutura e metabolismo da lagoa.

Palavras-chave: macrófita aquática, biomassa, nutrientes, composição química, poluição.

\section{INTRODUCTION}

Most coastal lagoons may be characterized as shallow environments. Despite their great ecological, social, and economic importance, coastal lagoons are among the Brazilian ecosystems most exposed to anthropic impacts (Esteves, 1998) since they are environments that receive several kinds of inorganic and organic matter from neighboring systems (Kjerfve, 1994). Although most lagoons along the Brazilian coast are subject to anthropic influence, no studies have been done on them that would allow for evaluation of consequent changes in their ecosystems (Branco et al., 1998).

The Imboassica Lagoon, located in the city of Macaé (RJ), has a mean depth of $1.09 \mathrm{~m}$, a maximum depth of $2.0 \mathrm{~m}$, and an area of $3.26 \mathrm{~km}^{2}$ (Panosso et al., 1998). This ecosystem has been subject to several kinds of anthropic impact, largely due to organic nutrient input from residential neighborhoods and the artificial breaching of the sandbar (Branco et al., 1998).

A considerable amount of organic pollutants is dumped into the lagoon, a large proportion of which is retained by the plant community, which is comprised of emergent and floating vegetation close to the nutrient input sources (Lopes-Ferreira $\&$ Pasin, 1998). According to studies by Petrucio \& Furtado (1998), the lagoon presents distinct regions of nutrient concentrations.

The Imboassica Lagoon has been classified as oligohaline and considered a well- buffered environment because of its alkalinity, a characteristic attributed to the strong influence of the ocean (Petrucio, 1998). The general abiotic conditions of the lagoon have been shown to favor the development of large stands of Charophytes, which often cover the entire benthic region of the lagoon (Petrucio \& Esteves, 1998).

Most Charophyte species are found in mineralized waters and develop a strong crust of calcium carbonate, particularly in phosphate-poor waters (Margalef, 1983; Wetzel, 1993). Charophytes are a common component in the littoral zone in oligotrophic and moderately eutrophic water bodies and may play a role in nutrient cycling in lakes with dense
Chara beds (Kufel \& Kufel, 2002). In the Imboassica Lagoon, this macroalgae is an important habitat for several macroinvertebrate species (Albertoni et al., 2001).

The ability of aquatic macrophytes to retain nutrients, especially nitrogen and phosphorus, sometimes beyond their immediate metabolic needs (Wetzel, 1993) makes the study of the distribution and chemical composition of these plants particularly important in understanding aquatic system ecology.

Several authors have studied the role of aquatic plants as nutrient and energy reservoirs, commonly focusing on their possible use in management strategies. This research indicates that submerged macrophytes, acting along with emergent or floating macrophytes, may enhance the total water quality (Reddy et al., 1982; Reddy, 1983, apud Reddy et al., 1987).

The submerged macrophyte Chara absorbs phosphorus throughout its entire structure, and the phosphorus absorbed by the rhyzoids is translocated to other portions of the plant (Littlefield \& Forsberg, 1965, apud Wetzel, 1993), suggesting that this macroalgae has great potential for nutrient retention. In the Imboassica Lagoon, Charophytes constitute an important autotrophic community and present rapid growth after drawdowns (Palma-Silva et al., 2002a, b).

This research aimed to study the distribution and variation of the biomass of Charophytes and nutrient concentration at different sites in the lagoon so as to establish the role of this plant community as a nutrient and energy pool.

\section{MATERIAL AND METHODS}

The samplings of Charophytes, both for estimating biomass and analyzsing chemical composition and energy content, took place at 6 sampling stations in the Imboassica Lagoon (St1 to St6) in October 1995 and November 1996, periods when the sandbar is closed and a great abundance of the macrophyte is found in almost all of the lagoon benthic region.

The sampling stations were chosen to represent a range of environmental characteristics in different parts of the lagoon. St1, the area closest to the sandbar, 
has a stronger marine influence, while St2 and St5 had higher nutrient concentrations, since both are located close to the source of domestic sewage inputs. $\mathrm{St} 3$ is an intermediate area between St2 and St4, with the latter representing the central body of the lagoon; St6 is closest to the great stands of emergent aquatic macrophytes at the Imboassica River mouth.

The samples for the biomass estimates were obtained from three quadrats $(25 \times 25 \mathrm{~cm})$ at each station, at a depth of approximately 0.8 meters.

On each sampling date, the $\mathrm{pH}$ value was obtained with a digital pHmeter; the dissolved oxygen concentration, determined by the Winkler method, modified by Golterman et al. (1978); the alkalinity value, with the titulometric method described by Carmouze (1994); the salinity value, with a refractometer; and the temperature, with a digital thermistor. We also collected water to determine total nitrogen (Mackereth et al., 1978), and total phosphorus content (Golterman et al., 1978).

At the laboratory, Charophytes were washed in running water and placed in an oven. After the first drying, the material was cleaned again to eliminate any remaining extraneous matter so that dry weight values could be determined. It was then ground for chemical analyses.

The concentration of total biomass nitrogen was determined using the micro-Kjedahl method (Allen et al., 1974), while that of total phosphorus was done with the method proposed by Fassbender (1973). The amount in each sample was determined by dichromate oxidation (EMBRAPA, 1997); energy value was obtained with a calorimetric microbomb, Phillipson model.

The ratio between the nutrient concentrations in the biomass of Charophytes was calculated for each sampling station using the median values for each nutrient $\left(\mathrm{mg} \cdot \mathrm{g}^{-1}\right)$. The total amount of nutrients and energy in the Charophytes beds was determined by multiplication with area biomass values.

Comparison of biomass chemical composition values in all the stations was done with the nonparametric Kruskal-Wallis test, and the Spearman correlation was used to analyze the relationship between nutrient concentration in the biomass and in the water column.

\section{RESULTS}

Charophytes were found at all stations except St1. Two species were identified: Chara angolensis
A. Braun and C. fibrosa Agardh ex Bruz. Emend. R.D. Wood, but these species were considered as a single group.

The values for biomass; concentrations of carbon, nitrogen, and phosphorus; energy values of the Charophytes (Table 1); and the values of the abiotic variables in the water column (Table 2 ) show the wide range of the results.

The results for carbon, energy value, and nitrogen in Oct. 1995 did not vary significantly ( $p>0.05)$ for the different stations. However, there were significant differences between phosphorus concentrations $(\mathrm{p}<0.05)$ at sampling stations St3 and St5, and those at St4 and St6 in the same period.

In Nov. 1996, nitrogen was significantly lower at $\mathrm{St} 3$ than at St4 $(\mathrm{p}<0.05)$ but no significant differences in phosphorus concentration were detected between these stations. Moreover, on this date significant differences $(\mathrm{p}<0.05)$ were registered between $\mathrm{St} 2$ and $\mathrm{St} 5$ for the energy value variable, and St 3 and St6 for carbon.

The ratio between nutrient concentrations in the biomass for each sampling station (Table 3) ranged from a maximum C:N of 24:1 in Nov. 1996 at St3, to a minimum of 12:1 at St5 in Oct. 1995. The highest C:P ratio, 872:1, was also recorded in Nov. 1996 (St6). The minimum C:P ratio of 387:1 was observed in Oct. 1995 at St3.

There was a wide range in N:P ratios. The maximum and minimum $\mathrm{N}: \mathrm{P}$ ratios were $47: 1$ and 19:1, both in Nov. 1996, at St6 and St3 respectively.

Minimum and maximum energy values were

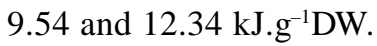

The total amount of nutrients and energy in the Charophyte beds (Table 4) showed maximum nutrient values of $1823 \mathrm{kgC} \cdot \mathrm{ha}^{-1}, 82.1 \mathrm{kgN} \cdot \mathrm{ha}^{-1}$, and $3.2 \mathrm{kgPha}^{-1}$. The maximum energy value was $4590 \mathrm{~kJ} . \mathrm{m}^{-2}$.

The correlation matrix between variables of plant and water nutrients was significant for nitrogen $r_{s}=0.45(p<0.05)$, and very significant for phosphorus $r_{s}=0.50(p<0.01)$, both with $n=30$.

\section{DISCUSSION}

In neither year were Charophytes observed at St1. This area is characterized by fine sand dominance and greater marine influence than the other stations (Gonçalves et al., 1998), which may not provide favorable conditions for development or fixation. 


\section{Biomass of Charophytes}

The total range of biomass values extended from 172 to $510 \mathrm{gDW} \cdot \mathrm{m}^{-2}$, with no significant differences between stations or sampling times. Kufel $\&$ Kufel (2002) found a range of 42 to $500 \mathrm{gDW} . \mathrm{m}^{-2}$. The biomass values found in the literature vary considerably and are probably related to specific characteristics and environmental conditions, though many are within the range recorded here. According to Howard-Williams (1978), in a saline lake in a temperate region the biomass of $C$. globularis ranged from 50 to $140 \mathrm{gDW} \cdot \mathrm{m}^{-2}$. For the Piratininga Lagoon on the coast of Rio de Janeiro values of between 500 and $700 \mathrm{gDW} \cdot \mathrm{m}^{-2}$ are recorded for Chara spp. in the period of maximum biomass (Carneiro et al., 1994). An average biomass value of $305 \mathrm{gDW} \cdot \mathrm{m}^{-2}$, influenced by wave exposure, water level fluctuation, and irradiance variations was found by Schwarz \& Hawes (1997) in a large oligotrophic lake in New Zealand. According to Blindow (1992), the biomass values of $C$. tomentosa were 465 and $478 \mathrm{gDW} \cdot \mathrm{m}^{-2}$ in two different Swedish lakes, and Kufel \& Ozimek (1994) found biomass values for Chara spp. of 417 gDW. $\mathrm{m}^{-2}$ in a mesotrophic lagoon in Poland. According to Forsberg (1960), a range of between 700 and 1130 g.m ${ }^{-2}$ was found in a Swedish lake, while Rickett (1924, apud Forsberg, 1960) mentions a biomass of $662 \mathrm{~g} \cdot \mathrm{m}^{-2}$.

\section{Nutrient concentration in biomass}

The values of nutrient concentration in the Charophyte biomass in the Imboassica Lagoon varied considerably (Table 1). Macroalgae have a smaller structural carbon proportion than angiosperms (Hutchinson, 1975). According to Duarte (1992), carbon concentration in a great variety of macroalgae ranged from 89 to $484 \mathrm{mg} . \mathrm{g}^{-1} \mathrm{DW}$. The results obtained ranged from approximately 325 to $392 \mathrm{mg} . \mathrm{g}^{-1} \mathrm{DW}$, slightly above the average value of around $250 \mathrm{mg} \cdot \mathrm{g}^{-1} \mathrm{DW}$ suggested by Duarte (op. cit.), but within the usual range for this group.

The nutrient concentration in the biomass may vary between different groups of photosynthetic organisms. According to Duarte (1992), nitrogen $(\mathrm{N})$ and phosphorus $(\mathrm{P})$ concentrations tend to be higher in phytoplankton than in macrophytes, and great variation exists in nutrient concentration in the many aquatic macrophyte groups.

Based on the minimum concentration of nitrogen (15 mg.g $\left.{ }^{-1} \mathrm{DW}\right)$ (Fujita et al., 1989) and phosphorus (1.3 mg. $\left.\mathrm{g}^{-1} \mathrm{DW}\right)$ (Gerloff \& Krombholz,
1966) necessary for maximum growth, Duarte (1992) observed that many macroalgae exhibit nitrogen concentration below the critical concentration, and also that their growth may be limited by phosphorus in the natural environment.

According to Schuette \& Alder (1929), Chara sp. has a nitrogen concentration of $7.2 \mathrm{mg} \cdot \mathrm{g}^{-1} \mathrm{DW}$ and a phosphorus concentration of $0.6 \mathrm{mg} . \mathrm{g}^{-1} \mathrm{DW}$. The authors concluded that this species had a smaller nitrogen concentration and a smaller amount of cellulosic matter than other submerged macrophytes, although it was responsible for half of the primary production of macrophytes in the lake studied.

Wile (1975) found lower concentrations of phosphorus (between 0.3 and $1.2 \mathrm{mg} \cdot \mathrm{g}^{-1} \mathrm{DW}$ ) and nitrogen (ranging from 5 to $15 \mathrm{mg} . \mathrm{g}^{-1} \mathrm{DW}$ ) in Chara sp. Similar average values were mentioned by Duarte (1992), with $19 \mathrm{mg} \cdot \mathrm{g}^{-1} \mathrm{DW}$ for nitrogen, ranging from 4.0 to $44.0 \mathrm{mg} . \mathrm{g}^{-1} \mathrm{DW}$, and phosphorus with an average value of $1.0 \mathrm{mg} \cdot \mathrm{g}^{-1} \mathrm{DW}$, ranging from 0.1 to $4.5 \mathrm{mg} . \mathrm{g}^{-1} \mathrm{DW}$. Data obtained from two Swedish lakes by Blindow (1992) showed that $C$. tomentosa presented a nitrogen concentration ranging from 10.5 to $14 \mathrm{mg} . \mathrm{g}^{-1} \mathrm{DW}$ and a phosphorus concentration of between 0.63 and $0.8 \mathrm{mg} . \mathrm{g}^{-1} \mathrm{DW}$.

The results of this study show that Charophytes had a phosphorus concentration ranging from 0.45 to $0.85 \mathrm{mg} . \mathrm{g}^{-1} \mathrm{DW}$ and a nitrogen concentration of between 14 and $27 \mathrm{mg} . \mathrm{g}^{-1} \mathrm{DW}$ and, therefore, within the expected range.

\section{$C: N: P$ ratios}

The C:N:P ratio between the concentrations of the major nutrients is commonly used to interpret the growth conditions to which a species is exposed. These ratios (Table 5) were high, ranging from $872: 47: 1$ to $387: 24: 1$, reflecting the nitrogen and phosphorus deficiencies in the biomass of Chara spp.

According to Gerloff \& Krombholz (1966), the ratio between nutrient concentrations varies relatively little along geographic gradients, since plants accumulate nutrients selectively. On the other hand, according to Garten (1976), frequent variation in the chemical composition of individuals of the same species at different sites is probably the result of lack of interest in studies of the ratios within or between species.

The Redfield C:N:P ratio for oceanic phytoplankton is 106:16:1 (Redfield et al., 1963, apud Duarte, 1992). For aquatic macrophytes, values as high as 500:25:1 are mentioned (Atkinson \& Smith, 
1983; Duarte, 1990). These values indicate that nutrient amounts required to maintain a given level of primary production is much smaller in marine benthic plants than in phytoplankton. According to Duarte (1992), the average ratios for macroalgae were the highest $(800: 49: 1)$. The values found for Charophytes are, therefore, within the expected range.

Variarions in the Redfield ratio are commonly used to infer the limiting nutrient in phytoplankton studies. An N:P ratio higher than 30 indicates a phosphorus deficiency; when smaller than 10, a nitrogen deficiency exists (Atkinson \& Smith, 1983). Results presented by Gerloff \& Krombholz (1966) show that freshwater macrophytes in highly fertile environments have an average N:P ratio of 15:1, while those found in less fertile ones have a ratio of 30:1.

For Chara sp. in the Piratininga Lagoon, Carneiro et al. (1994) found that the N:P ratio ranged from 5:1 (in the period of rapid growth) to 50:1. From the $\mathrm{N}: \mathrm{P}$ ratios ranging between 47:1 and 19:1 obtained in the Imboassica Lagoon, phosphorus was considered to be a limiting nutrient, and the constant input of phosphorus from sewage discharge frequently led to low N:P ratios at $\mathrm{St} 2, \mathrm{St} 3$, and $\mathrm{St} 5$.

According to Atkinson \& Smith (1983), the wide range detected in nutrient ratios of marine macroalgae is probably due to environmental conditions; they also point out that in poorer environments the $\mathrm{C}: \mathrm{N}$ and $\mathrm{C}: \mathrm{P}$ ratios are significantly higher than in areas with greater nutrient input. The results of this research are similar for the $\mathrm{C}: \mathrm{P}$ ratio, with the highest values found for St6. However, this was not clear for the $\mathrm{C}: \mathrm{N}$ ratio, since $\mathrm{St} 2$, which had a greater concentration of nutrients in the water column, had the highest values (Table 3 ).

\section{Energy in biomass}

Due to lower carbon concentration values, macroalgae have a lower energy value than aquatic angiosperms. According to Boyd \& Goodyear (1971), the small variation in the energy content found in aquatic macrophyte biomass is mainly the result of the strong balance in the protein, lipid, and carbohydrate concentration. However, according to Handoo et al. (1988), the energy content may present significant intra- and interspecific variation in several aquatic macrophyte species in several sites of the same lake.

According to Grabowski (1973), submerged aquatic macrophytes have values close to $11.1 \mathrm{~kJ}$. $\mathrm{g}^{-1} \mathrm{DW}$; floating macrophytes, $15.4 \mathrm{~kJ} \cdot \mathrm{g}^{-1} \mathrm{DW}$; and

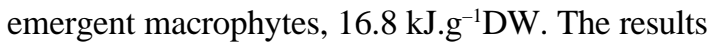

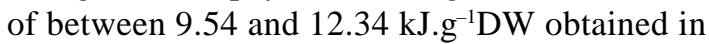
this research are close to the mean value mentioned, and are lower than those of other aquatic macrophytes found in the north of Rio de Janeiro State. For floating macrophytes, Thomaz \& Esteves (1986) found a variation of between $16.9 \mathrm{~kJ}^{-1} \mathrm{gW}$ and

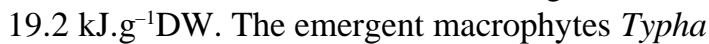
domingensis and Eleocharis cf fistulosa in the Imboassica Lagoon had average values of 19.18 and

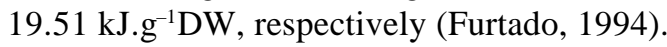

TABLE 1

Median values of biomass, carbon, nitrogen, and phosphorus concentration, and energy values of Charophytes at sampling stations in Oct. 95 and Nov. 96.

\begin{tabular}{|c|c|c|c|c|c|c|c|}
\hline \multirow{2}{*}{ Variables } & \multirow{2}{*}{ Date } & \multicolumn{6}{|c|}{ Sampling stations } \\
\hline & & St1 & St2 & St3 & St4 & St5 & St6 \\
\hline \multirow{2}{*}{$\begin{array}{l}\text { Biomass } \\
\text { gDW.m }{ }^{-2}\end{array}$} & Oct. 95 & - & 172 & 209 & 193 & 222 & 246 \\
\hline & Nov. 96 & - & 330 & 310 & 330 & 510 & 380 \\
\hline \multirow{2}{*}{$\begin{array}{c}\text { Carbon } \\
\mathrm{mg} \cdot \mathrm{g}^{-1} \mathrm{DW}\end{array}$} & Oct. 95 & - & 357.59 & 329.22 & 330.62 & 326.43 & 325.04 \\
\hline & Nov. 96 & - & 349.68 & 331.55 & 384.09 & 357.59 & 392.46 \\
\hline \multirow{2}{*}{$\begin{array}{c}\text { Energy } \\
\text { Value } \\
\mathrm{kJ} . \mathrm{g}^{-1} \mathrm{DW}\end{array}$} & Oct. 95 & - & 11.46 & 10.17 & 9.54 & 10.29 & 10.21 \\
\hline & Nov. 96 & - & 11.55 & 12.34 & 11.05 & 9.00 & 10.29 \\
\hline \multirow{2}{*}{$\begin{array}{l}\text { Nitrogen } \\
\mathrm{mg} \cdot \mathrm{g}^{-1} \mathrm{DW}\end{array}$} & Oct. 95 & - & 18.2 & 20.7 & 19.2 & 27.0 & 19.0 \\
\hline & Nov. 96 & - & 16.7 & 14.0 & 22.5 & 16.1 & 21.0 \\
\hline \multirow{2}{*}{$\begin{array}{l}\text { Phosphorus } \\
\text { mg.g } .^{-1} \mathrm{DW}\end{array}$} & Oct. 95 & - & 0.63 & 0.85 & 0.51 & 0.75 & 0.52 \\
\hline & Nov. 96 & - & 0.73 & 0.73 & 0.49 & 0.62 & 0.45 \\
\hline
\end{tabular}




\section{Quantity of nutrients and energy}

Determination of energy stock per unit area $\left(\mathrm{kJ} . \mathrm{m}^{-2)}\right.$ provides important basic information for understanding the role of macrophytes in the energy flow of aquatic environments (Grabowski, 1973). In our study, the total nutrient and energy amount in the Charophyte beds (Table 4) suggests that this species is an important factor in the metabolic dynamics of the lagoon.
The total nutrient stock retained in the stands of this macroalgae showed the importance of their role. It should be noted that the combined values of total biomass per unit area and the nutrient concentration in the macrophyte biomass made of St5 and St6, sites considered less enriched than St2, the main nutrient storage areas. It is probable that this plant reaches higher biomass values in sites with lower turbity and higher transparency.

TABLE 2

Water column variables at different sampling stations, Imboassica Lagoon, Oct. 95 and Nov. 96.

\begin{tabular}{|c|c|c|c|c|c|c|c|}
\hline \multirow{2}{*}{ Variables } & \multirow{2}{*}{ Date } & \multicolumn{6}{|c|}{ Sampling stations } \\
\hline & & St1 & St2 & St3 & St4 & St5 & St6 \\
\hline \multirow{2}{*}{$\begin{array}{l}\text { N-total } \\
\left(\mathrm{mg} \cdot \mathrm{L}^{-1}\right)\end{array}$} & Oct. 95 & 0.45 & 0.64 & 0.61 & 0.35 & 0.70 & 0.60 \\
\hline & Nov. 96 & 0.34 & 0.41 & 0.40 & 0.42 & 0.56 & 0.42 \\
\hline \multirow{2}{*}{$\begin{array}{l}\text { P-total } \\
\left(\mu \mathrm{g} . \mathrm{L}^{-1}\right)\end{array}$} & Oct. 95 & 27.1 & 55.0 & 34.1 & 20.8 & 51.7 & 25.8 \\
\hline & Nov. 96 & 26.4 & 45.5 & 23.1 & 22.0 & 35.9 & 17.1 \\
\hline \multirow{2}{*}{$\begin{array}{c}\text { Temperature } \\
\left({ }^{\circ} \mathrm{C}\right)\end{array}$} & Oct. 95 & 24.5 & 24.3 & 24.5 & 22.5 & 24.3 & 24.1 \\
\hline & Nov. 96 & 25.8 & 25.8 & 26.0 & 26.0 & 26.0 & 26.0 \\
\hline \multirow{2}{*}{$\begin{array}{c}\text { Salinity } \\
\left(\%^{\mathrm{o}}\right)\end{array}$} & Oct. 95 & 6.8 & 6.4 & 4.1 & 6.4 & 4.6 & 3.4 \\
\hline & Nov. 96 & 1.0 & 0.0 & 0.0 & 0.0 & 0.0 & 0.0 \\
\hline \multirow{2}{*}{$\mathrm{pH}$} & Oct. 95 & 7.98 & 7.02 & 6.91 & 7.20 & 6.72 & 6.23 \\
\hline & Nov. 96 & 8.72 & 8.34 & 7.56 & 8.89 & 8.63 & 8.31 \\
\hline \multirow{2}{*}{$\begin{array}{l}\text { Alkalinity } \\
\left(\text { Eq.L }{ }^{-1}\right)\end{array}$} & Oct. 95 & 0.184 & 0.203 & 0.190 & 0.129 & 0.167 & 0.032 \\
\hline & Nov. 96 & 0.150 & 0.143 & 0.096 & 0.116 & 0.122 & 0.132 \\
\hline \multirow{2}{*}{$\begin{array}{l}\text { Oxygen } \\
\left(\mathrm{mg} \cdot \mathrm{L}^{-1}\right)\end{array}$} & Oct. 95 & 7.23 & 6.12 & 7.17 & 7.10 & 6.24 & 7.05 \\
\hline & Nov. 96 & 8.53 & 6.90 & 7.53 & 9.55 & 7.19 & 9.41 \\
\hline
\end{tabular}

TABLE 3

C:N:P ratios for Charophytes from stations where they occurred in Oct. 95 and Nov. 96.

\begin{tabular}{|c|c|c|c|c|c|}
\hline Stations & Date & Carbon & Nitrogen & Phosphorus & C:N \\
\hline \multirow{3}{*}{ St2 } & Oct. 95 & 568 & 29 & 1 & $20: 1$ \\
\cline { 2 - 6 } & Nov. 96 & 479 & 23 & 1 & $21: 1$ \\
\hline \multirow{3}{*}{ St3 } & Oct. 95 & 387 & 24 & 1 & $16: 1$ \\
\cline { 2 - 6 } & Nov. 96 & 454 & 19 & 1 & $24: 1$ \\
\hline \multirow{3}{*}{ St4 } & Oct. 95 & 648 & 38 & 1 & $17: 1$ \\
\cline { 2 - 6 } & Nov. 96 & 784 & 46 & 1 & $17: 1$ \\
\hline \multirow{3}{*}{ St5 } & Oct. 95 & 435 & 36 & 1 & $12: 1$ \\
\cline { 2 - 6 } & Nov. 96 & 577 & 26 & 1 & $17: 1$ \\
\hline \multirow{2}{*}{ St6 } & Oct. 95 & 625 & 37 & 1 & $19: 1$ \\
\cline { 2 - 6 } & Nov. 96 & 872 & 47 & 1 & 1 \\
\hline
\end{tabular}


TABLE 4

Estimated values of Carbon, Nitrogen and Phosphorus (kg.ha $\left.{ }^{-1}\right)$, and Energy $\left(\mathrm{kJ}^{\mathrm{m}} \mathrm{m}^{-2}\right)$ for Charophytes at each sampling station in Oct. 95 and Nov. 96.

\begin{tabular}{|c|c|c|c|c|c|}
\hline Date & Station & Carbon & Nitrogen & Phosphorus & Energy \\
\hline \multirow{4}{*}{ Oct. 95 } & St2 & 615.1 & 31.3 & 1.1 & 1971.1 \\
\cline { 2 - 6 } & St3 & 688.1 & 43.3 & 1.8 & 2125.5 \\
\cline { 2 - 6 } & St4 & 638.1 & 37.1 & 1.0 & 1841.2 \\
\cline { 2 - 6 } & St5 & 724.7 & 59.9 & 1.7 & 2284.4 \\
\cline { 2 - 6 } & St6 & 799.6 & 46.7 & 1.3 & 2511.7 \\
\hline \multirow{4}{*}{ Nov. 96 } & St2 & 1153.9 & 55.1 & 2.4 & 3811.5 \\
\cline { 2 - 6 } & St3 & 1027.8 & 43.4 & 2.3 & 3825.4 \\
\cline { 2 - 6 } & St4 & 1267.5 & 74.3 & 1.6 & 3646.5 \\
\cline { 2 - 6 } & St5 & 1823.7 & 82.1 & 3.2 & 4590.0 \\
\cline { 2 - 6 } & St6 & 1491.3 & 79.8 & 1.7 & 3910.2 \\
\hline
\end{tabular}

\section{Correlations between nutrient concentration in biomass and water}

Studies based on the analysis of aquatic macrophyte biomass assume that the concentration of a given element in an organism has a large range, in response to environmental concentration (Wetzel, 1993).

When nitrogen and phosphorus concentrations in the biomass of Charophytes show a positive correlation with the concentration of these nutrients in the water column, this indicates that the macroalgae may have a "buffer effect" on these concentrations. However, the intensity of absorption is not great enough to result in a decrease of this nutrient concentration in the water column.

Analyzing a wide variety of macrophytes, Garten (1976) found a strong positive correlation between nitrogen and phosphorus concentrations in non-vascular plants, including Charophytes. $\mathrm{He}$ concluded that the evolution of the nutrient ratios must be related to the maintenance of a chemical balance inside the cells, maximizing protein synthesis and biomass production in natural environments. Similar results were presented by Duarte (1992).

The results showed a significant positive correlation between these nutrient concentrations in the biomass, indicating an active metabolism on the part of the macroalgae due to ready availability of nutrients in the environment.

The community of Charophytes forms thick beds in the benthic zone of the Imboassica Lagoon and is the most common submerged aquatic macrophyte in the system. Its spatial distribution is not homogeneous, and the plants are not found close to the sandbar (St1), which is the area with the strongest marine influence. At the other sampling stations, there were no significant differences in the biomass on each sampling date, but the highest values were observed in Nov. 1996. The concentrations of carbon, nitrogen, and phosphorus were similar to values reported in the literature. Based on the $\mathrm{C}: \mathrm{N}: \mathrm{P}$ ratios, phosphorus was considered to be a limiting nutrient. The positive correlations between the phosphorus and nitrogen concentrations in the macroalgae biomass and in the water suggest that macrophyte responds to changes in nutrient concentration in the aquatic environment. The nutrient and energy concentration values in the plant, combined with its biomass values, show that Charophytes are an important biological nutrient reservoir in the Imboassica Lagoon, and also that the largest nutrient amounts are usually retained in the less enriched sampling stations.

Acknowledgements - We thank PETROBRAS, CAPES, and CNPq for financial support; Dr. Sidinei M. Thomaz, Dra. Yocie Y. Valentin, Dr. Fábio R. Scarano, and Dr. Reinaldo L. Bozelli for suggestions; and Dra. Norma Catarina Bueno for the identification of Charophytes during this research.

\section{REFERENCES}

ALBERTONI, E. F., PALMA-SILVA, C. \& ESTEVES, F. A., 2001, Macroinvertebrates associated with Chara in a tropical coastal lagoon (Imboassica Lagoon, Rio de Janeiro, Brazil). Hydrobiologia, 457: 215-224. 
ALLEN, S. E., GRIMSHAW, H. M., PARKINSON, J. A. \& QUARMBY, C., 1974, Chemical analysis of ecological materials. Blackwell Scientific Publications, Oxford, 565p.

ATKINSON, M. J. \& SMITH, C. V., 1983, C:N:P ratios of benthic plants. Limnol. Oceanogr., 28: 568-574.

BLINDOW, I., 1992, Long- and short-term dynamics of submerged macrophytes in two shallow eutrophic lakes. Freshwat. Biol., 28: 15-27.

BOYD, C. E. \& GOODYEAR, C. P., 1971, Nutritive quality of food in ecological systems. Arch. Hydrobiol., 69: 256-270.

BRANCO, C. W. C., ATTAYDE, J. L. \& KOZLOWSKY-SUZUKI, B., 1998, Zooplankton community of a coastal lagoon subjected to anthropogenic influences (Lagoa Imboacica, Macaé, R.J., Brazil). Verh. Internat. Verein. Limnol., 26: 1426-1429.

CARMOUZE, J. P., 1994, O metabolismo dos ecossistemas aquáticos: fundamentos teóricos, métodos de estudo e análises químicas. Edgard Blücher/FAPESP, São Paulo, $254 \mathrm{p}$

CARNEIRO, E. R. M., AZEVEDO, C., RAMALHO, N. M. \& KNOPPERS, B., 1994, A biomassa de Chara hornemannii em relação ao comportamento físico-químico da lagoa de Piratininga (RJ). An. Acad. Bras. Ci., 66: 213-222.

DUARTE, C. M., 1990, Seagrass nutrient content. Mar. Ecol. Prog. Bot., 27: 195-201.

DUARTE, C. M., 1992, Nutrient concentration of aquatic plants: Patterns across species. Limnol. Oceanogr, 37: 882-889.

EMBRAPA, 1997, Manual de métodos de análise de solo. 2a ed., EMBRAPA, Rio de Janeiro, 212p.

ESTEVES, F. A., 1998, Lagoas costeiras: origem, funcionamento e possibilidades de manejo, Cap. 2.1, pp. 63-87. In: F. A. Esteves (ed.), Ecologia das lagoas costeiras do Parque Nacional da Restinga de Jurubatiba e do Município de Macaé $(R J)$. NUPEM/UFRJ, Rio de Janeiro, 464p.

FASSBENDER, H. W., 1973, Simultane P-Bestimmung im NKjeldahl-aufschlu von Bodenproben. Die Phosphorsäure, 30: 44-53.

FORSBERG, C., 1960, Subaquatic macrovegetation in Ösbysjön, Djursholm. Oikos, 11: 183-199.

FUJITA, R. M., WHEELER, P. A. \& EDWARDS, R. L., 1989, Assessment of macroalgal nitrogen limitation in a seasonal upwelling region. Mar. Ecol. Prog. Ser., 53: 293-303.

FURTADO, A. L. S., 1994, Contribuição das macrófitas aquáticas Typha domingensis Pers (Typhaceae) $e$ Eleocharis cf fistulosa (Poir.) Link (Cyperaceae) para o estoque de nutrientes e energia da lagoa Imboacica (Macaé, RJ). Dissertação de Mestrado, Programa de Pós-graduação em Ecologia, Depto. de Ecologia, UFRJ, 104 p. + tab.

GARTEN, C. T., 1976, Correlations between concentrations of elements in plants. Nature, 261: 686-688.

GERLOFF, G. C. \& KROMBHOLZ, P. H., 1966, Tissue analysis as a measure of nutrient availability for the growth of angiosperm aquatic plants. Limnol. Oceanogr., 11: 529-537.

GOLTERMAN, H. L., CLYMO, R. S. \& OHMSTAD, M. A. M., 1978, Methods for physical and chemical analysis of fresh water. Blackwell Scientific Publ., Oxford, 214p.
GONÇALVES, J. F. JR., CALLISTO, M. F. P. \& FONSECA, J. J. L., 1998, Relação entre a composição granulométrica do sedimento e as comunidades de macroinvertebrados bentônicos nas lagoas Imboassica, Cabiúnas e Comprida, Cap. 3.2, pp. 99-122. In: F. A. Esteves (ed.), Ecologia das lagoas costeiras do Parque Nacional da Restinga de Jurubatiba e do Município de Macaé (RJ). NUPEM/UFRJ, Rio de Janeiro, 464p.

GRABOWSKI, A., 1973, The biomass, organic matter contents and calorific values of macrophytes in the lakes of the Szeszuga drainage area. Pol. Arch. Hydrobiol., 20: 269-282.

HANDOO, J. K., SARAF, N. \& KAUL, V., 1988, Energy content and ecological efficiency of macrophytes in Dal Lake, Kashmir. Arch. Hydrobiol., 111: 351-367.

HOWARD-WILLIAMS, C., 1978, Growth and production of aquatic macrophytes in a south temperate saline lake. Verh. Internst. Verein. Limnol., 20: 1153-1158.

HUTCHINSON, G. E., 1975, A treatise on limnology - limnological botany. V.III. John Willey \& Sons, New York, 660p.

KJERFVE, B., 1994, Coastal lagoon processes. In: B. Kjerfve (ed.), Coastal lagoon processes, pp. 1-8. Elsevier Oceanography Series n. 60, Amsterdam.

KUFEL, L. \& OZIMEK, T., 1994, Can Chara control phosphorus cycling in lake luknajno (Poland)? Hydrobiologia, 275/276: 277-283.

KUFEL, L. \& KUFEL, I., 2002, Chara beds acting as nutrient sinks in shallow lakes - a review. Aquat. Bot., 72: 249-260.

LOPES-FERREIRA, C. \& PASIN, E. B., 1998, Distribution of total nitrogen and phosphorus concentrations at the sewer outfall at Imboassica Lagoon, RJ, Brazil. Verh. Internat. Verein. Limnol., 26: 1491-1493.

MACKERETH, F. J. H., HERON, J. \& TALLING, J. F., 1978, Water analysis: some revised methods for limnologists. (scientific publication n. 36) Freshwater Biological Association, Cumbria and Dorset, England, 120p.

MARGALEF, R., 1983, Limnología. Omega, Barcelona, 1010p.

PALMA-SILVA, C., ALBERTONI, E. F. \& ESTEVES, F. A., 2002a, The role of Charophytes primary production in a coastal lagoon subjected to human impacts (RJ, Brazil). Acta Limnol. Bras., 14: 59-69.

PALMA-SILVA, C., ALBERTONI, E. F. \& ESTEVES, F. A., $2002 \mathrm{~b}$, Clear water associated with biomass and nutrient variation during the growth of a charophyte stand, in a tropical coastal lagoon after a drawdown. Hydrobiologia, 482: 79-87.

PANOSSO, R. F., ATTAYDE, J. L. \& MUEHE, D., 1998, Morfometria das lagoas Imboassica, Cabiúnas, Comprida e Carapebus: implicações para seu funcionamento e manejo, Cap. 3.1, pp. 91-108. In: F. A. Esteves (ed.), Ecologia das lagoas costeiras do Parque Nacional da Restinga de Jurubatiba e do Município de Macaé (RJ). NUPEM/UFRJ, Rio de Janeiro, 464p.

PETRUCIO, M. M., 1998, Caracterização das lagoas Imboassica, Cabiúnas, Comprida e Carapebus a partir da temperatura, salinidade, condutividade, alcalinidade, $\mathrm{O}_{2}$ dissolvido, $\mathrm{pH}$, transparência e material em suspensão, Cap.3.2, pp. 99-122. In: F. A. Esteves (ed.), Ecologia das lagoas costeiras do Parque Nacional da Restinga de Jurubatiba e do Município de Macaé (RJ). NUPEM/UFRJ, Rio de Janeiro, 464p. 
PETRUCIO, M. M. \& FURTADO, A. L. S., 1998, Concentrações de nitrogênio e fósforo da coluna d'água da lagoa Imboassica, Cap. 3.3, pp. 123-133. In: F. A. Esteves (ed.), Ecologia das lagoas costeiras do Parque Nacional da Restinga de Jurubatiba e do Município de Macaé (RJ). NUPEM/UFRJ, Rio de Janeiro, 464p.

PETRUCIO, M. M. \& ESTEVES, F. A., 1998, The influence of salinity on the uptake of nitrogen and phosphorus in the water by Eichhornia crassipes and Salvinia auriculata. Proceedings of the $6^{\text {th }}$ International Conference on Wetlands Systems for Water Pollution Control, pp. 524-534.

REDDY, K. R., CAMPBELL, K. L., GRAETZ, D. A. \& PORTIER, K. M., 1982, Use of biological filters for agricultural drainage water treatment. J. Environ. Qual., 11: 591-595.

REDDY, K. R., TUCKER, J. C. \& DEBUSK, W. F., 1987, The role of Egeria in removing nitrogen and phosphorus from nutrient enriched waters. J. Aquat. Plant. Manage., 25: 1419.
SCHUETTE, H. A. \& ALDER, H., 1929, A note on the chemical composition of Chara from Green Lake, Wisconsin. Trans. Wis. Acad. Sci. Arts. Lett., 24: 141-145.

SCHWARZ, A. M. \& HAWES, I., 1997, Effects of changing water clarity on characean biomass and species composition in a large oligotrophic lake. Aquat. Bot., 56: 169-181.

THOMAZ, S. M. \& ESTEVES, F. A., 1986, Valores energéticos da biomassa de algumas espécies de macrófitas aquáticas tropicais. Cien. Cult., 38: 1691-1695.

WETZEL, R. G., 1993, Limnología. Fundação Calouste Gulbenkian, Lisboa, 919p.

WILE, I., 1975, Lake restoration through mechanical harvesting of aquatic vegetation. Verh. Internat. Verein. Limnol., 19: 660-671. 